\section{E-LOGOS}

ELECTRONIC JOURNAL FOR PHILOSOPHY ISSN 1211-0442

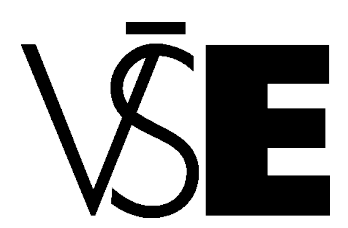

University of Economics

Prague

\title{
Od polovzdělanosti k nevzdělanosti
}

\author{
Vladimír Kyprý
}

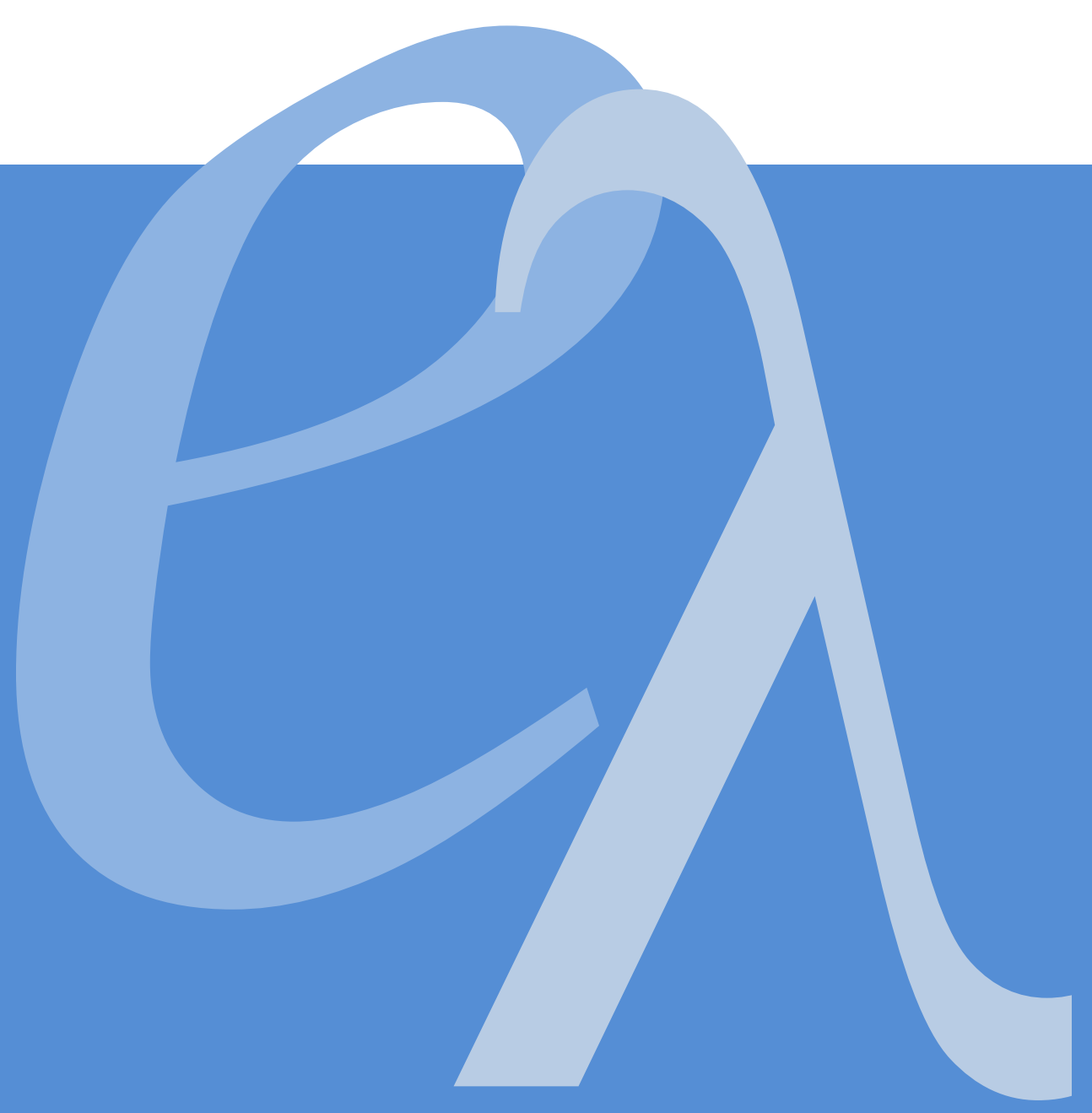




\begin{abstract}
This article - review - "From semi-education till non-education" - deals with K. P. Liessmann's book "Theory of non-education"; in the track of it, it thinks over and thinks to the end questions as follows: 1. What is the former founding and aiming relation to the idea of education? 2. What is the present (founding out of it and aiming against it) relation to the idea of education? 3 . What is the founding and aiming contraidea of the contemporary „education“? 4. What is the founding and aiming contra-idea of "education" in contemporary "educational institutions" (especially in schools as "educational institutions")? 5. What is the essential foundation of the founding and aiming contra-idea of the contemporary "education“ (i. e. also: what is the essential foundation of the founding and aiming contra-idea of "education" in contemporary "educational institutions", i. e. also in schools as "educational institutions")? - This article - review - "From semi-education till non-education“ -, dealing with K. P. Liessmann's book "Theory of non-education" and (in the track of it) thinking over and thinking to the end those questions, adds an appendix concerning the structure of the contemporary educational system; according to it, the structure of the contemporary educational system consists in (higher) schools-factories and (lower) school-sewers as well as in an association of (higher) schools-factories and (lower) schools-sewers, i. e. in the association by a sliding limit, namely by a limit sliding only upwards, not downwards.
\end{abstract}

Keywords: semi-education, non-education, education, idea of education; educational institutions, schools as educational institutions; essential foundation of the contemporary idea of (non)education and of educational process, essential foundation of contemporary educational institutions and of schools as educational institutions. 


\section{Abstrakt}

Tato stat" - recenze - „Od polovzdělanosti k nevzdělanosti“ - se zabývá knihou K. P. Liessmanna „Teorie nevzdělanosti“; $v$ jejích stopách promýšlí a domýšlí tyto otázky: 1. Jaký je dřívější zakládající a zacilující vztah $\mathrm{k}$ ideji vzdělanosti? 2. Jaký je nynější vztah $\mathrm{k}$ ideji vzdělanosti, zakládající se mimo ni a zacilující se proti ní? 3. Jaká je zakládající a zacilující antiidea dnešního „vzdělávání“? 4. Jaká je zakládající a zacilující antiidea „vzdělávání“ v dnešních „vzdělávacích institucích“, zvláště pak ve školách jako „vzdělávacích institucích“? 5. Jaký je bytný základ zakládající a zacilující antiideje dnešního „vzdělávání“ (tj. i jaký je bytný základ zakládající a zacilující antiideje "vzdělávání" v dnešních „vzdělávacích institucích“, tj. i ve školách jako „vzdělávacích institucích“)? - Tato recenzní stat' - „Od polovzdělanosti k nevzdělanosti“, zabývajíc se knihou K. P. Liessmanna „Teorie nevzdělanosti“ a v jejích stopách promýšlejíc a domýšlejíc ony otázky, dodává dodatek o struktuře dnešního školství, dle nějž struktura dnešního školství tkví v rozdělení na vyšší školy - továrny a nižší školy stoky i v propojení vyšších škol - továren a nižších škol - stok posuvnou hranicí, tj. hranicí posuvnou pouze směrem nahoru, nikoli ovšem směrem dolů.

Klíčová slova: polovzdělanost, nevzdělanost, vzdělání, idea vzdělanosti; vzdělávací instituce, školy jako vzdělávací instituce; bytný základ současné ideje (ne)vzdělanosti a vzdělávání, bytný základ současných vzdělávacích institucí a škol jako vzdělávacích institucí. 
K. P. Liessmann ve své knize „Teorie nevzdělanosti“ ${ }^{1}$ navazuje na knihu T. W. Adorna „Teorie polovzdělanosti“ ${ }^{2}$ a dokazuje, že za padesát let došla ((post)moderní) "společnost vědění" od šíření polovzdělanosti k šíření nevzdělanosti: to je padesátiletý "pokrok“ ((post)moderní) „společnosti vědění“. Ukazuje a dokazuje to fenomenálně (na fenoménech dnešní doby i "society“) i fenomenologicky (fenomenologickou redukcí z fenoménů dnešní doby i „,society“) tak, že proti tomu nelze nic (či takřka nic) namítat. Zvláště pak proti tomu nelze nic (či takřka nic) namítat tomu, kdo ve sféře "vzdělanosti“ (tj. ve sféře nedovzdělanosti či polovzdělanosti či nevzdělanosti) sám přímo působil či tak či tak dosud sám přímo působí.

Jaké jsou hlavní momenty Liessmannovy analýzy ((post)moderní) ${ }^{3}$ ",společnosti vědění"? Lze říci, že hlavní momenty Liessmannovy analýzy ((post)moderní) "společnosti vědění" jsou tyto: 1. dřivější zakládající a zacilující vztah k ideji vzdělanosti; 2. nynější vztah k ideji vzdělanosti, zakládající se mimo ni a zacilující se proti ní; 3. zakládající a zacilující antiidea dnešního „vzdělávání“; 4. zakládající a zacilující antiidea „vzdělávání“ v dnešních „vzdělávacích institucích“, zvláště pak ve školách jako „vzdělávacích institucích“; 5. bytný základ zakládající a zacilující antiideje dnešního „vzdělávání“ (tj. i bytný základ zakládající a zacilující antiideje „Vzdělávání“ v dnešních „vzdělávacích institucích“, tj. i ve školách jako „vzdělávacích institucích“). Jejich základní význam je antropologicko-ontologický; vyjádřeme je tedy ve stručné (a snad hutné) antropologicko-ontologické zkratce, tj. vyjádřeme je spíše esenciálně nežli fenomenálně. ${ }^{4}$

\section{Dřívější zakládající a zacilující vztah $k$ ideji vzdělanosti.}

Osvícenskou a humanistickou (resp. osvícensko-humanistickou) ideou vzdělanosti byla idea vzdělávání jako sebeutváreni člověka, tj. sebeutváreni, jímž člověk se stává svébytnou (a svéprávnou) bytostí, tj. jímž se stává bytostí jsoucí na svém vlastním bytném základě, resp. bytostí jsoucí soým vlastním bytným základem a na něm se dějící, tj. na něm vše činící. ${ }^{1}$

Bytost jsoucí na svém vlastním bytném základě, resp. bytost jsoucí svým vlastním bytným základem, tj. bytost svébytná a svéprávná, musí být (osvicensko-)humanisticky vzdělaná - a není jiného nežli humanistického (osvícenského) vzdělání, jež je programem utváreni člověka duchovni prací, resp. programem duchovniho sebeutváreni člověka v jeho životě a pro jeho život.

\section{Nynější vztah k ideji vzdělanosti, zakládající se mimo ni a zacilující se proti ní.}

Dnes (v dnešní (post)moderní "společnosti věděni") osvícenská a humanistická (resp. osvícensko-humanistická) idea vzdělanosti, jež byla ideou vzdělávání jako sebeutvářní člověka, tj. sebeutvářeni, jimž člověk se stává svébytnou (a svéprávnou) bytostí, tj. jímž se stává bytostí jsoucí na svém vlastním bytném základě, resp. bytostí jsoucí soým vlastním bytným základem 
a na něm se dějici, tj. na něm vše činicí, je potlačena a opuštěna, neb je nepotřebná, a je nahrazena

představou (antipredstavou) bytosti nejsoucí na svém vlastním bytném základě, resp. bytosti nejsoucí soým vlastním bytným základem, tj. bytosti nesvébytné a nesvéprávné, jež nemůže být (osvícensko-)humanisticky vzdělaná, a není-li jiného nežli humanistického (osvicenského) vzděláni, tedy s programem utváření člověka duchovni prací, resp. s programem duchovního sebeutvářní člověka v jeho životě a pro jeho život, nemá nic společného, resp. popř. s ním má něco společného jen v programu „celoživotního vzděláváni"; avšak program „celoživotního vzděláváni“ je jen paskvilem na vzděláváni, tj. paskvilem, v němž vzdělávání je též potlačeno a opuštěno, neb je nepotřebné, a nahrazeno dnes (v dnešni (post)moderní „společnosti věděni") ... čím?

\section{Zakládající a zacilující antiidea dnešního "vzdělávání“.}

$V$ dnešni ((post)moderní) "společnosti věděni" je zakládající a zacilující antiideou dnešniho „vzděláváni" služba industriálnímu provozu, tj. provozu industrializovaného dění bytí lidsky jsoucího, resp. spíše dění bytí antilidsky jsoucího, standardně produkujícího produkty lidské (pseudo)potřebnosti a standardně konzumujícího lidsky (pseudo)potřebné produkty, a to bez ohledu na bytostné lidské potřeby, resp., bytostně lidsky vzato, bezohledně a nepotřebně.

Je-li v dnešní ((post)moderní) "společnosti věděni" zakládající a zacilující antiideou dnešnîho „vzděláváni" služba industriálnímu provozu, tj. provozu industrializovaného dění bytí lidsky jsoucího, resp. spíše dění bytí jsoucího antilidsky (bezohledného k bytostným lidským potřebám, tj., bytostně lidsky vzato, bezohledného a pseudopotřebného),

pak se dnešní "vzděláváni" redukuje na profesní vyučení pro onu službu; "teorie vzdělanosti", pro niž se dnešní "vzděláváni" redukuje na profesní vyučení pro onu službu, tudiž, vzhledem ke klasické tradici (vzhledem ke klasicky tradiční teorii vzdělanosti), spiše nežli teorii vzdělanosti je "teorií nevzdělanosti".

Kým podle ní má být, resp. má se stát, vyučenec k té službě? Má se stát a být mobilním a flexibilním agentem industriálního provozu, jenž se dle potřeb industriálního provozu mobilně, flexibilně a agilně v něm umíst'uje a přemíst'uje, jsa „vzdělán“, aby dělal, co „,je třeba“, tj. cokoli, co „je třeba“, tj. po čem je poptávka na „trhu práce“",1 nebot' poptávka na "trhu práce“ rozhoduje - resp. má zcela rozhodovat - o tom, oč jde v dnešním „vzdělávání“ a co je dnešní „vzdělávání“:

je produktem, jejž lze produkovat a s nímž lze i obchodovat

- což „vyžaduje“ "management vědění“

a což tedy „vyžaduje“ i své „manažery vědění“ - 
a jejž lze odhazovat či vyhazovat, tj. produktem, jenž bud' umožňuje mobilitu, disponibilitu etc. $\mathrm{v}$ industriálním provozu, nebo mobilitu, disponibilitu etc. neumožňuje, a industriální provoz si žádá jiný: a co si žádá, musí mít.

A kým podle ní má být, resp. má se stát, vyučující k té službě? Též se má stát a být mobilním a flexibilním agentem industriálního provozu, jenž dle potřeb industriálního provozu „vzdělává“ mobilní a flexibilní agenty k umístění a přemístění v něm, aby dělali, co „je třeba“, tj. cokoli, co „je třeba“, tj. po čem je poptávka na "trhu práce ${ }^{\prime \prime}{ }^{2}$ nebot' poptávka na "trhu práce“ pro něj o všem rozhoduje, resp. má zcela rozhodovat o tom, oč jde v dnešním „vzdělávání“ a co je dnešní „vzdělávání“.

Podstatným momentem industriálního provozu je ovšem moment ekonomistický. ${ }^{3}$

Nakolik pak podstatným momentem industriálního provozu je onen ekonomistický moment, ${ }^{4}$

natolik pak služba industriálnímu provozu je službou jeho (podstatnému,) ekonomistickému momentu,

tzn. že dnešní „vzděláváni" ve službě industriálního provozu je podstatně službou jeho ekonomistickému momentu, jímž dnešní „vzděláváni“ je kontrolováno a ovládáno.

Proto (pro to vše) tedy se dnešni "vzděláváni“ redukuje na profesní vyučení pro onu službu a pro to vše je tudiž "teorie vzdělanosti“, pro niž se dnešni "vzděláváni" na profesní vyučení pro onu službu redukuje, vzhledem ke klasické tradici (vzhledem ke klasicky tradiční teorii vzdělanosti) spíše nežli teorií vzdělanosti "teorii" nevzdělanosti.

\section{Zakládající a zacilující antiidea "vzdělávání" $\mathrm{v}$ dnešních "vzdělávacích institucích", zvláště pak ve školách jako „vzdělávacích institucích“.}

Vše výše zde uvedené ${ }^{1}$ o zakládající a zacilující antiideji „vzdělávání“ platí i pro dnešní „vzdělávací instituce“, tj. také pro školy jako „vzdělávací instituce“.

Důsledkem toho všeho je, že dnešní školy se staly či stávají továrnami na "vzděláni"; v těchto továrnách na „vzdělání“, dnešních školách, došlo k industrializaci „vzdělávání" ve výše určeném smyslu, ${ }^{2}$ a to od budování studijních programů přes způsoby výuky (tj. přes způsoby výroby „vzdělání“)3 až do normování studijních výkonů a publikačních výkonů, v nichž nejde o dílo, tj. o duchovní sílu díla, o jeho duchovní význam, ale v nichž jde právě jen o publikační výkon, jemuž se (za nějž se) dle norem (ryze kvantitativních či kvazikvalitativních norem) přidělují - předpisují publikační body: za takovou a takovou formu publikace tolik a tolik publikačních bodů bez ohledu na to, zda jde o dílo duchovně silné, či zda jde o dílo slabé, bezduché - na to se ohled nebere a nelze jej brát: na to „není čas“ a nesmí „být čas“: ten, kdo přiděluje - předpisuje - publikační body („evaluátor ${ }^{\prime \prime}$ ), tak činí, aniž by četl to, co 
„evaluuje“, či alespoň řádek z toho přečetl; odtud i služby a protislužby „evaluátorů“ a „evaluovaných“ apod., nebot' to vše je nejen založeno, ale též zacíleno čistě ekonomisticky či především ekonomisticky (tak např. publikace jsou pro publikační body a publikační body, tzn. i publikace, jsou pro peníze - pro normovaný a nárokovaný příděl peněz: pro co jiného nežli pro to?). A tak $\mathrm{s}$ industrializací „Vzdělávání“ došlo i k vládě ekonomistického ohledu v něm a pohledu na ně, tj. ohledu a pohledu ekonomisticky kvantitativního (kvantitativistického), tj. odlidštěného, s omezováním a potlačováním všeho jiného (ještě lidského - neodlidštěného: kvalitationího, esenciálnîho, natož pak existenciálnîho). Odtud a proto továrny na „vzdělání“, dnešní školy, vedou mezi sebou i konkurenční boj na „trhu se vzděláním“, tj. na trhu s nevzdělaností; tento konkurenční boj, jejž mezi sebou dnešní školy (továrny na „Vzdělání“) vedou, je boj ne různého, ale stejného: boj o „místo na slunci“, tj. o posty „na slunci“ - v nejtemnější temnotě, jež je (suma sumárum) důsledkem toho všeho: temnota snad temnější než v době Temna a v "temných stoletích“.

To vše se týká též a zvláště všech "vysokých škol“ i škol "nejoyšších" - univerzit.

I na univerzitách v důsledku toho, že dnešní školy se takto staly či stávají továrnami na „vzděláni" a že i univerzity jsou dnes továrnami na „vzdělání“, tak jako jiné školy, došlo k industrializaci vzdělávání ve výše určeném smyslu, ${ }^{4}$ a to i ve způsobech výuky (tj. ve způsobech výroby „vzdělání“), ${ }^{5}$ a s industrializací "vzdělávání“ došlo i zde $\mathrm{k}$ vládě ekonomistického ohledu $\mathrm{v}$ něm a pohledu na ně, tj. ohledu a pohledu ekonomisticky kvantitativního (kvantitativistického), tj. odlidštěného, s omezováním a potlačováním všeho jiného (ještě lidského - neodlidštěného, kvalitativního a dalšího vyššího). A odtud a proto i univerzity, tak jako jiné školy - továrny na „vzdělání", vedou mezi sebou i konkurenční boj na "trhu se vzděláním", tj. na trhu s nevzdělaností; a i tento konkurenční boj, jejž mezi sebou i univerzity, tak jako jiné školy - továrny na „vzdělání“, vedou, je boj ne různého, ale stejného: týž boj o "místo na slunci“, tj. o posty "na slunci“ - v nejtemnější temnotě, jež je (suma sumárum) důsledkem toho všeho i zde: i zde temnota snad temnější než $\mathrm{v}$ době Temna a „V temných stoletích".

To vše, týká-li se též a zvláště všech "vysokých škol" i škol "nejvyšších" - univerzit,

znamená, že to, co dělá v klasickém smyslu univerzitu univerzitou: pěstování humanitních věd a vyučování humanitním vědám, tj. humanistický duch, se potlačuje a likviduje (anti)duchem antihumánním ve službách industriálního provozu, popř. se transformuje tak, že se zařazuje do služeb industriálnímu provozu, at' už si ponechává jméno „humanitních věd“, či at' už (spíše a raději) si ani jméno humanitních věd (jako nepotřebnou př́itěž, popř. přítěž - ještě? - nebezpečnou) neponechává.

Jestliže však to, co dělá v klasickém smyslu univerzitu univerzitou, se potlačuje a likviduje nebo se transformuje a zařazuje, 
pak tedy vzhledem ke klasickému smyslu termínu "univerzita" je "univerzita" již prázdným (oyprázdněným) termínem:

chce se jen ještě týt z aureoly jména „univerzita“,

přestože se pojem univerzity (i s aureolou jména, $z$ nějž se chce ještě týt) odstraňuje, likviduje.

A odstraňuje-li se a likviduje

a je-li vzhledem ke klasickému smyslu termínu "univerzita" dnes „univerzita" již prázdným (oyprázdněným) termínem,

pak tedy prestávají být „univerzity“ univerzitami

a stávají se „vy̌̌šími odbornými školami“ (či spišse vyššími „odbornými“ učilišti):

"univerzity" dnes jsou - a pribývají - pouze nominálně,

kdežto reálně dnes univerzit ubývá, resp. spiše již nejsou.

Dálo-li se tak dřrive ideologickou cestou,

děje se tak nyní cestou ekonomistickou, jež ovšem má svou ideologii, je tedy též sui generis ideologická.

To apod. platí navíc k výše zde uvedenému 6 o zakládající a zacilující antiideji „vzdělávání“ pro dnešní „vzdělávací instituce“, tj. také pro školy jako „vzdělávací instituce".

5. Bytný základ zakládající a zacilující antiideje dnešního "vzdělávání“ (tj. i bytný základ zakládající a zacilující antiideje "vzdělávání“ v dnešních "vzdělávacích institucích", tj. i ve školách jako "vzdělávacích institucích").

(Anti)bytným základem likvidace, anihilace ideje vzdělanosti a vzdělávání v dnešni době i likvidace, anihilace vzdělávacích institucí jako institucí vskutku vzdělávacích, včetně ztovárnění škol včetně univerzit a tím i likvidace univerzit transformací na školní továrny, etc., je "kapitalizace ducha", resp. - lépe řě̌eno - kapitalistický antiduch, tj. antiduch superkapitálu, ${ }^{1}$

jenž je vědění přátelsky nakloněn jen tehdy, lze-li vědění bezprostředně (ekonomisticky) zhodnotit;

nelze-li vědění bezprostředně (ekonomisticky) zhodnotit, je od něj nepřátelsky odkloněn.

To znamená, že vědění jako takové se stává nesvéprávným (nesvébytným),

že přestává být svéprávným (svébytným); jako takové má vědění se vzděláním (se vskutku vzděláním) vskutku málo společného, ne-li nic společného. 
To vše má společensko-dějinný rámec:

Antiduch superkapitálu zvítězil nad svým soupeřem (protějškem) reálsocialistickým antiduchem,

a po vítězství nad antiduchem reálsocialismu týž antiduch superkapitálu normalizuje všechny bytné sféry „society“, jíž vládne, bezprostředně k svému obrazu. (V normalizaci některých bytných sfér "society", jíž vládne, bezprostředně k jeho obrazu mu dříve něco bránilo - mj. ohled k soupeři - protějšku; nyní mu v tom nic nebrání, tedy je - může být - bezohledný.)

To se v „societě“, jíž vládne, týká i bytné sféry „vzdělávací“:

i „vzdělávací" bytná sféra v „societě“, jíž vládne, ztrácí svou autonomii, resp. zbytky své autonomie - tzn. že autonomii, resp. zbytky autonomie, v ní ztrácí i autonomně (tj. humanisticky, na humanistické bázi) myslící a činící jedinec tváří v tvář přítomnosti a „budoucnosti“ industriálního provozu: ve "světlé“ přítomnosti a ještě "světlejší" "budoucnosti“ industriálního provozu není pro autonomně (tj. humanisticky, na humanistické bázi) myslícího a činícího jedince místo - je z ní "vymístěn“ i jako adresát vzdělávání i jako aktér vzdělávání, tj. nezávislý bádající duch - ,

tj. ztrácí ráz vskutku vzdělávání

a nabývá rázu antivzdělávacího:

stává se a je pouze učilištěm pro potřeby industriálního provozu, tj. antiducha superkapitálu v něm:

vždyt' konec konců potřeby industriálního provozu a jeho učiliště jsou právě a zvláště potřebami antiducha a superkapitálu,

jsou potřebami antiducha na bázi superkapitálu - vládce nad všemi bytnými sférami "society“, tj. nad "societou“ se všemi bytnými sférami bez výjimky: zrušení, znemožnění všech výjimek je cílem posledního (vítězného?) tažení antiducha superkapitálu, tj. tažení antiducha na bázi superkapitálu za globální - totální vládou nad světem. Unifikace světa pod jeho vládou - tot' globální, totální obsah postmoderní doby; veškerá "pluralizace“ pak je v postmoderní době ve světě pod jeho vládou pouhou pestrostí, ${ }^{2}$ tj. pouhou vnějškovostí horečně a horlivě „živého“ a "činného“ porůznu namaškařeného a namaskovaného, pózujícího a posunčivého, žvanivého a blábolivého, rozeřvaného a řvavého ... téhož: vždy téhož horečně a horlivě "živého“ a „činného" rozeřvance (porůznu namaškařeného a namaskovaného, pózujícího a posunčivého, žvanivého a blábolivého a řvavého etc.), to jest vždy téhož "zahnívajícího" a „umírajícího“ antiducha superkapitálu, jenž však snad je s to - jak si ještě neuměl představit Lenin, jak si však my po Leninovi už představit umíme "zahnívat" a „umírat" „na věky věkův", to jest do konce lidských věků. 
To je společensko-dějinný rámec,

$\mathrm{v}$ němž se anihiluje, likviduje idea vzdělanosti a vzdělávání v dnešni době a v němž se i vzdělávací instituce jako instituce vskutku vzdělávací likvidují, anihilují (včetně ztovárnění škol včetně univerzit a tím i likvidace univerzit transformací na školní továrny etc.) na (anti)bytném základě "kapitalizace ducha", tj. kapitalistického antiducha - antiducha superkapitálu. ${ }^{2}$

Co z toho (suma sumárum) plyne pro onoho "vymístěného", autonomně (tj. humanisticky - na humanistické bázi) myslícího a činícího jedince - nezávislého bádajícího ducha?

Pro onoho "vymístěného", autonomně (tj. humanisticky - na humanistické bázi) myslícího a činícího jedince - nezávislého bádajícího ducha z toho (suma sumárum) plyne,

že ve "vzdělávaci" bytné sfére dnešni "society" je vskutku vzděláváni a vskutku vzdělanost nemožná,

tzn. že vskutku vzdělávání a vskutku vzdělanost dnes je možná jen mimo „vzdělávací" bytnou sféru dnešni "society": ve sfére jedinečného lidského bytí a (spolu)jedinečného lidského spolubytí: na existenciálních ostrovech, popř. i na existenciálních souostrovích, jež dnes jsou $i$ mohou být i jedinými (posledními) ostrovy (souostrovími) vzdělávání a vzdělanosti. ${ }^{3}$

Lze říci, že toto jsou hlavní momenty Liessmannovy analýzy ((post)moderní) ${ }^{1}$ „společnosti vědění": 1. dřivější zakládající a zacilující vztah k ideji vzdělanosti; 2. nynější vztah k ideji vzdělanosti, zakládající se mimo ni a zacilující se proti ní; 3. zakládající a zacilující antiidea dnešního „vzdělávání“; 4. zakládající a zacilující antiidea „vzdělávání“ v dnešních „vzdělávacích institucích“, zvláště pak ve školách jako „vzdělávacích institucích“; 5. bytný základ zakládající a zacilující antiideje dnešního „vzdělávání“ (tj. i bytný základ zakládající a zacilující antiideje „vzdělávání“ v dnešních „vzdělávacích institucích“, tj. i ve školách jako „vzdělávacích institucích“). Jaké jsou hlavní momenty Liessmannovy analýzy ((post)moderní) "společnosti vědění“ v jejich základním významu antropologicko-ontologickém, jsem zde vyjádřil ve stručné (a snad hutné) antropologicko-ontologické zkratce, tj. vyjádřil jsem je spíše esenciálně nežli fenomenálně. ${ }^{2}$

Navazuje-li tedy K.-P. Liessmann ve své knize „Teorie nevzdělanosti“ ${ }^{3}$ na knihu T. W. Adorna "Teorie polovzdělanosti“" ${ }^{4}$ a dokazuje-li tedy, že za padesát let došla ((post)moderní) „společnost vědění“ od šíření polovzdělanosti k šíření nevzdělanosti, což je padesátiletý "pokrok“ ((post)moderní) "společnosti vědění", a ukazuje-li a dokazuje-li to fenomenálně (na fenoménech dnešní doby i "society“) i fenomenologicky (fenomenologickou redukcí z fenoménů dnešní doby i „society“), pak proti tomu nelze nic (či takřka nic) namítat. Zvláště pak proti tomu nelze nic (či takřka nic) namítat tomu, kdo ve sféře „vzdělanosti“ (tj. ve sféře nedovzdělanosti či 
polovzdělanosti či nevzdělanosti) sám př́imo působil či tak či tak dosud sám přímo působí.

Liessmannova kniha „Teorie nevzdělanosti“ prý měla v Rakousku i jinde velký (veřejný) úspěch a velký (veřejný) úspěch v Rakousku i jinde měl i sám Liessmann za knihu „Teorie nevzdělanosti“ byl prohlášen „vědcem r. 2006“ a je tedy dnes „vyhlášeným vědcem“. Není-li to potěšující? Bylo by to potěšující, není-li to úspěch u těch, kteří jsou oporami (post)moderní "společnosti vědění" a jejího fungování a prolongování ad infinitum, at' už jsou oporami onoho "vědění" (a odtud i této společnosti) či at' jsou oporami této společnosti (a odtud i onoho „vědění"), a kteří, jsouce oporami (post)moderní "společnosti věděni" a jejího ad infinitum prolongovaného fungování, usoudili, že pro ně (i pro jejich věc) bude momentálně vhodná a výhodná „imidž“ příznivců kritického myšlení, resp. př́íznivců kritického myslitele, a tedy si ji, tu momentálně vhodnou a výhodnou imidž, nasadili. Že je to „úspěch“ právě a zvláště u těchto farizejů - nebot' jejich je „vzdělávací“ bytná sféra dnešní "society“, z níž pochází ony pochvaly -, je zřejmé - a je to zřejmé též z toho, že „vzdělávací“ bytná sféra dnešní „,society“, jež je jejich a z níž ony pochvaly pochází, se nemění a nezmění. Pro Liessmannovu knihu "Teorie nevzdělanosti“ však tento „úspěch“ neznamená nic: Liessmannova kniha „Teorie nevzdělanosti“ je (přes tento „úspěch“, jenž pro ni nic neznamená) kniha silná, protože se v ní pojí silný logos a přísný étos - jež při zkoumání lidských věcí musejí kráčet pospolu; nekráčejí-li pospolu, nemůže zkoumání lidských věcí jít k pravdě ani k pravdě dojít - a přestože ji pochválil ten či ten dnešní farizej, přestože ji pochválil dokonce sám p. H. ...

\section{Dodatek: škola - továrna a škola - stoka.}

K. P. Liessmann se v „Teorii nevzdělanosti“ zabývá dnešní „společností vědění“, pokud jde o "vzdělávací instituce“, zvláště pak o školy jako „vzdělávací instituce“, především na (nej)vyšší úrovni, tj. na úrovni škol - továren, méně již na úrovni (nej)nižší, tj. na úrovni škol - stok. I ty však patří k dnešní „společnosti vědění“ a svým zpo̊sobem ji charakterizují, tj. doplňují svým způsobem její charakteristiku.

Já sám jsem v jedné takové škole - stoce (tj. v jedné pražské "střední odborné škole a středním odborném učilišti“) takřka čtyři roky pobýval a mohu ji z vlastní zkušenosti charakterizovat takto:

V oné antiškole antistudenti ukazují (pod)učitelům jen vůli nic nedělat a mít (zvykové) právo nic nedělat, a projít s osvědčením, že „vystudovali“ „školu“", přestože nikdy (naprosto nikdy!) nestudovali a ve škole (vskutku škole) nepobývali.

A v téže antiškole (pod)učitelé uznávají vůli antistudentů nic nedělat a jejich zvykové právo nic nedělat, a s osvědčením, že "vystudovali“ "školu“, přestože naprosto nikdy nestudovali (a ve škole - tj. v skutku škole - nepobývali), moci projít; 
nic proti tomu nenamítají a nic proti tomu nepodnikají: „brát plat a chtít víc“ - tot’ jediná podučitelská idea, resp. jediná antiidea živnostenského podučitelství, v jehož živnostenském antiduchu není už žádná známka ducha poslání a povolání.

(Jsou to trpaslíci ducha "aprobovani“" dle trpasličí míry, vlastníci trpasličí „kvalifikace“, tj. "kvalifikace“, již „maji”, nehledě na to, co jsou a co umějí, resp. neumějí. Tito trpaslíci ducha, dle trpasličí míry "aprobovaní", „mají "kvalifikaci“ a tuto „kvalifikaci“, již "mají“, nehledě na to, co jsou a co umějí, tj. že nic neumějí a ničemu nerozumějí a nechtějí rozumět a nic nedělají a nechtějí dělat, si „neustále zvyšuji“"; "neustále zvyšovat“" pak znamená účastnit se školení, kde „školiteli“ jsou podučitelé jim podobní a kde tito jim podobní podučitelé - „školitelé“ jim „rozšíří obzor" - či "rozšíří obzory“ - nicotnosti a povrchnosti dalšími nicotnostmi a povrchnostmi - např. dalšími "fakty“ a faktíčky -, jež nevedou a nemohou vést k porozumění ničemu; takže, nadále ničemu nerozumějíce, „účastníci školení“ obdrží osvědčení o proškolení, a obdrževše je, vyvěsí je a mají je vyvěšené - mají certifikát, a jako vlastníci certifikátu takto vlastní i „zvýšenou kvalifikaci“ - a takto dál „zvyšují“ - „neustále zvyšují“! - svou "kvalifikaci“, tj. neustále takto zvyšují svou nicotnost a povrchnost; avšak ani ji nejsou s to předat svým klientům - antistudentům, neb jejich klienti - antistudenti in principio nepřijímají a nechtějí přijímat nic - ani nicotnost a povrchnost svých (pod)učitelů, protože jsou in principio neučitelní.)

Kdo je hlavní viník této karikatury školy, tohoto paskvilu na školu?

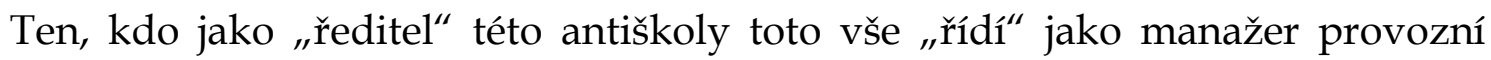
nicoty: kdo jako „ředitel“ této antiškoly toto vše „,̌̌ídí“ tak, že zajišt'uje chod prázdné (bezobsažné) formy provozu antiškoly, tj. tak, že zajištuje, aby provoz antiškoly prázdně (bezobsažně), formálně fungoval dle "předpisư“: aby se šiřila a hloubila nevzdělanost a aby ani stín vzdělanosti nepadl do stoky; kdo o tom řeční a kdo o tom píše;

ten, jehož všechny př́ípisy jsou jen o „předpisech“ fungování provozu antiškoly (provozní stoky nicoty), nikoli o proměně a nutnosti - povinnosti proměny antiškoly ve školu;

ten, jehož všechny výkřiky jsou jen o výkladech a případech "předpisů“ fungování provozu antiškoly (provozní stoky nicoty), nikdy v nich nic není o proměně a nutnosti - povinnosti proměny antiškoly na školu.

Opravdový ředitel školy by si byl vědom nutnosti - povinnosti proměny antiškoly ve školu a udělal by vše, aby antiškolu ve školu proměnil, a raději by na místo ředitele školy rezignoval, nežli by byl pouhým antiředitelem antiškolní stoky, tj. manažerem provozní nicoty.

Opravdový antiředitel antiškoly si není vědom žádné povinnosti, leda nutnosti zachovat antiškolní živnost a udělat vše, aby živnost antiškoly zachoval; nežli by na 
místo ředitele školy rezignoval, raději je antiředitelem nejhorší antiškolní stoky, tj. provozním manažerem nicoty.

Opravdový ředitel školy by dbal na to, co je podstatou a posláním školy a co je podstatou a posláním učitele ve škole, pokud není a pokud nechce být podučitelem, tj. na výuku a vzdělání (výukou ke vzdělání); nebyl by ignorantem, pro něhož to vše je „samozřejmé“ a jenž chce (nad to vše "samozřejmé“) „něco navíc“, tj. "projekty“ úniku a útěku od poslání školy a od poslání a podstaty učitele ve škole k podučitelství. Proto by se staral, s jakými podklady a na jakých základech kdo učí, jaký studijní program k tomu vypracoval, a vyžadoval by, aby vedl ke vzdělanosti, aby byl příspěvkem ke vzdělanosti, tzn. prohloubený a ucelený a komponovaný, a pokud by nebyl, tedy by jej nepřipustil - nepodepsal: nepodepisoval by mechanicky "schválil“ nic bezkoncepčního, bezkoncepčně nedbalého a neschopného. Odtud by se ovšem staral též o to, jak kdo učí, zda s ideálem hloubení vzdělanosti, nebo reálně šiř̀e nevzdělanost, a nepřipustil by, aby „učili“ bezkoncepční, bezkoncepčně nedbalí a neschopní podučitelé.

Proto, neignoruje to podstatně obsažné na škole, nemusel by simulovat nejsoucí obsahy a úrovně obsahů: nemusel by provozovat „šaušpílerství“, nemusel by být „šaušpílerem“, 1 jenž „prezentuje“ - tj. imituje - svůj antiprodukt jako Produkt a producíruje se při svých „prezentacích“ (imitacích) nestoudným a nehorázným vykřikováním a vytrubováním, že je nejlepší: nechtěl by být producírujícím se tajtrlíkem - povykujícím a pokřikujícím trpaslíkem ducha, protože by nechtěl být „nejlepším“" „šaušpílerem“ - hochštaplerem.

Opravdový antiředitel antiškoly nedbá na to, co je podstatou a posláním školy a co je podstatou a posláním učitele ve škole, pokud není a pokud nechce být podučitelem, tj. na výuku a vzdělání (výukou ke vzdělání); je vždy již ignorantem, pro něhož to vše je "samozřejmé“ a jenž chce (nad to vše "samozřejmé“) „něco navíc“, tj. „projekty“ (!), jež ovšem jsou jen únikem a útěkem od podstaty a poslání školy a od poslání a podstaty učitele ve škole k podučitelství. Proto se vůbec nestará, s jakými podklady a na jakých základech kdo učí, jaký studijní program k tomu vypracoval, a vůbec nevyžaduje, aby vedl ke vzdělanosti, aby byl příspěvkem ke vzdělanosti, tzn. prohloubený a ucelený a komponovaný, ani ho nenapadne, že, pokud jím není, tedy by jej neměl připustit - neměl podepsat: to ho ani ve snu nenapadne a podepisuje mechanicky „schválil“" vše bezkoncepční, bezkoncepčně nedbalé a neschopné nekomponovanou (resp. dekomponovanou) hromadu všeho možného libovolného, na hromadu libovolně naházeného bez ucelenosti, natož pak prohloubenosti, vedoucí jen $k$ nevzdělanosti, jsoucí jen př́ispěvkem $k$ roztahující se a rozšiřující se nevzdělanosti, tj. ovšem příspěvkem na nejnižší možné úrovni: na nižší úrovni to snad již není a snad nemůže být možné. Odtud se ovšem nestará ani o to, jak kdo učí, a nejenže připouští, aby učili bezkoncepční, bezkoncepčně nedbalí a neschopní 
podučitelé, ale též si je pěstuje a prosazuje jako své bližní: podučitelé jsou bližními antiředitele a antiředitel si s podučiteli (i s antistudenty - klienty (!)) "rozumi“: "rozumí" si s nimi, mluvě stejnou „ř̌číi”, tj. mluvě stejnými řečmi provozní nicoty provozní živnosti, jsa týž pokleslý živnostník - agent antiducha bez učitelské ideje a bez známky ducha poslání a povolání, jako jsou týmiž pokleslými živnostníky bez známky poslání a povolání podučitelé - agenti antiducha a antiideje: v jeho službách on i oni šiŕrí nevzdělanost a v jeho službách on i oni "se živí“ - „jsou živi“ - šířením nevzdělanosti. ${ }^{2}$

Proto, ignoruje vše podstatně obsažné na škole, musí simulovat nejsoucí obsahy a úrovně: musí provozovat "šaušpílerství", musí být „šaušpílerem“,3 jenž „prezentuje“ - imituje - svůj antiprodukt jako Produkt a producíruje se při svých „prezentacích“ (imitacích) nestoudným a nehorázným vykřikováním a vytrubováním: „Jsme nejlepší!“ Hle, viz zde producírujícího se tajtrlíka - povykujícího, pokřikujícího trpaslíka ducha, jenž chce „být nejlepši““ ... „šaušpíler“ - hochštapler.

On je hlavní viník této karikatury školy, tohoto paskvilu na školu:

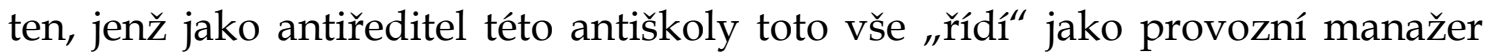
nicoty: kdo jako antiředitel této antiškoly toto vše „ř́idi““ tak, že zajištujue - či předstírá, že zajištuje -prázdný chod bezobsažné formy antiškolního provozu, tj. tak, že zajišt'uje - či předstírá, že zajišttuje -, aby antiškolní provoz prázdně (bezobsažně), formálně fungoval dle "předpisůu: aby se hloubila a šířila nevzdělanost a aby ani paprsek (či stín paprsku) vzdělanosti nepadl do stoky; ten, kdo o tom píše a kdo o tom řeční.

To tedy je on: provozní manažer nicoty antiškolní stoky, jenž nemá potuchy o tom, co znamená být ředitelem školy, jejímž posláním a povoláním je šiřrení a hloubení vzdělanosti, a jenž ani potuchy o tom, co znamená být ředitelem školy, tedy o poslání a povolání k šíření a hloubení vzdělanosti, mít nechce: chce být jen manažerem provozní nicoty antiškolní stoky jako své živnosti a tuto svou živnost si chce udržet stůj co stůj; udržet si ji znamená stůj co stůj získat (náborem, nikoli výběrem) antistudentskou klientelu v konkurenci s jinými antiškolami a antiřediteli antiškol a antistudentské klientele (v konkurenci s jinými antiřediteli) sloužit ve vší její nicotnosti i marnosti a vysloužit si tím pokračování a prodlužování své živnosti ve vší její z hlediska lidského bytí a smyslu lidského bytí - nicotnosti a marnosti, z jeho hlediska však výhodnosti a výživnosti; vždyt' hledisko výhodnosti a výživnosti živnosti je pro něho a spol. (pro antiředitele a podučitele, pro antiředitele podučitelů) jediným hlediskem, jímž hledí na školu a jímž ji mění - eo ipso mění - na antiškolu, na antiškolní stoku. - Toto tedy je on,

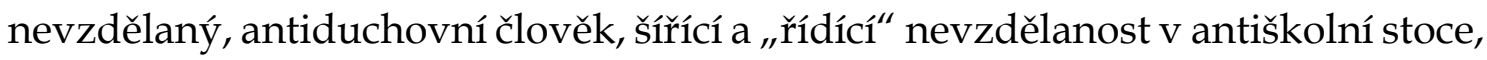
z níž si udělal svou živnost, tj. na nejnižší možné úrovni šiřrení a „ک̌rizení“ nevzdělanosti - v antiškolních stokách předělaných na živnosti, na této nejnižší možné úrovni se obklopující sobě podobnými podučiteli a konkurující si se sobě podobnými antiřediteli 
v soutěži o "nejlepšího" - tj. o nejhoršího možného nevzdělance a člověka antiduchovního. Necht' se mu, antiřediteli podučitelů, $v$ té tuhé soutěži i nadále (nadále a navždy) daří!

Takto mohu z vlastní zkušenosti charakterizovat jednu takovou školu - stoku (tj. jednu pražskou „střední odbornou školu a střední odborné učiliště“), kde jsem já sám takřka čtyři roky pobýval.

Zabývá-li se K. P. Liessmann v „Teorii nevzdělanosti“ dnešní "společností vědění“, pokud jde o „vzdělávací instituce“, zvláště pak o školy jako „vzdělávací instituce", tedy zvlášt' na (nej)vyšší úrovni, tj. na úrovni škol - továren; nicméně i úroveň (nej)nižší, tj. úroveň škol - stok, taky patří k dnešní "společnosti vědění“ a svým způsobem ji charakterizuje, tj. doplňuje svým zpo̊sobem její charakteristiku.

To je tedy obraz dnešního školství: obrazem dnešního školství tedy jsou stoky nepochybných antiškol, nad nimiž se "tyčí", nad nimiž "pyšně ční" továrny pochybných škol, a to tak, že mezi stokami nepochybných antiškol a továrnami pochybných škol je posuvná hranice a že posuvnost té hranice je dnes zřejmě možná (a nutná) jen směrem vzhůru, nikoli směrem dolů. - Ó požehnaný obraz „země vdovy po duchu“, ó obraz požehnané vlády antiducha nad vdoví zemí. 


\section{Poznámky a odkazy:}

\section{(K úvodu:)}

1 - Z r. 2006; česky vyšlo r. 2009.

2 - Z r. 1959; česky nevyšlo.

3 - Sám Liessmann mluví pouze o moderní době. Nepatří však fenomény přechodu „společnosti vědění“ od (polo)vzdělávání k nevzdělanosti i dalších pochodů "společnosti vědění" svým původem a svým vývojem k fenoménům doby postmoderní, tak jak ji určují i jak ji datují „postmoderni““ filosofové a historikové, resp. filosofové a historikové „postmoderny“, o níž sám Liessmann vůbec nemluví?

4 - Pokud jde o fenomenální stránku věci, o niž zde běží, můžeme ji zcela svěřit Liessmannově "Teorii nevzdělanosti“: je tam podána způsobem takřka vyčerpávajícím.

Pokud jde o esenciální stránku věci, o niž zde běží, můžeme v ní Liessmannovu "Teorii nevzdělanosti“ zpřesnit a podat ji tady způsobem ne snad vyčerpávajícím, leč přeci jen přesnějším, tj. ucelenějším, prohloubenějším a přehlednějším.

\section{Ad 1. (Dřívější zakládající a zacilující vztah k ideji vzdělanosti.)}

1 - Tak tomu rozuměl např. a zvláště W. v. Humboldt $\mathrm{v}$ „Teorii vzdělání člověka“, což je klasický výraz klasických představ o ideji vzdělanosti.

Právě zvláště na „Teorii vzdělání člověka“ W. v. Humboldta a na to, jak rozuměl ideji vzdělanosti (v klasickém výraze klasické představy),

navazuje T. W. Adorno v knize „Teorie polovzdělanosti“ a K. P. Liessmann v knize „Teorie nevzdělanosti“:

T. W. Adorno v knize „Teorie polovzdělanosti“ a K. P. Liessmann v knize „Teorie nevzdělanosti“, navazujíce na ni, ukazují a dokazují "vývoj” a "pokrok“ ideje vzdělávání člověka z klasické moderní doby do antiideje polo(ne)vzdělanosti člověka v době poklasické ((post)moderní).

Ad 2. (Nynější vztah k ideji vzdělanosti, zakládající se mimo ni a zacilující se proti ní.)

1 - Srov. zde výše, pozn. 1 ad 1. 


\section{Ad 3. (Zakládající a zacilující antiidea dnešního „vzdělávání“.)}

1 - Tj. ovšem na trhu "džobu“, nebot” "trh práce“ je součástí industriálního provozu; a je-li součástí industriálního provozu, je „trh práce“ vždy jen trhem "džobu“: v něm je práce deklasována a devalvována na svou výdělečnou funkci a ve své dělné funkci (tvořit dílo, tj. dobré dílo, a vytvořit je) je likvidována tak, jak je zlikvidován pojem díla i pojem dobra v rámci industriálního provozu: pro "hladký chod“ industriálního provozu je pojem díla a pojem dobra nejen přebytečný, ale popř. i nebezpečný. (To vše je výsledkem - jedním z výsledků převrácenosti - zvrácenosti ekonomického na ekonomistické, jež z lidsky služebného učinilo lidsky bytostné, tj. jež lidsky služebné povýšilo na lidsky bytostné, tj. jež učinilo z člověka lidského člověka ekonomického, resp. jež snížilo člověka na ekonomickém bytném podkladu žijícího na člověka nemohoucně živořícího, byt' i mohutně produkujícího a konzumujícího, na antibytném kvazizákladě ekonomistickém.)

2 - Viz zde výše pozn. 1 ad 3.

3 - Ekonomistické je ekonomické, jež se z lidsky služebného učinilo lidsky bytostným, tj. jež se z lidsky služebného povýšilo na lidsky bytostné, tj. jež učinilo z člověka lidského člověka ekonomického, resp. jež snížilo člověka na ekonomickém bytném podkladu žijícího na člověka (nemohoucně) živořícího (byt' i mohutně produkujícího a konzumujícího) na antibytném kvazizákladě ekonomistickém. (Výsledkem - jedním z výsledků - této převrácenosti - zvrácenosti - je ovšem i „trh práce“ a na „trhu práce“ deklasování a devalvování práce na její výdělečnou funkci a zlikvidování práce v její dělné funkci - tvořit dílo, tj. dobré dílo, a vytvořit je -, tak jak je zlikvidován pojem díla i pojem dobra v rámci industriálního provozu, neb pro „hladký chod“ industriálního provozu je pojem díla a pojem dobra nejen přebytečný, ale popř. i nebezpečný.)

4 - Viz zde výše pozn. 3 ad 3.

Ad 4. (Zakládající a zacilující antiidea „Vzdělávání“ v dnešních „Vzdělávacích institucích“, zvláště pak ve školách jako „vzdělávacích institucích“.)

1 - Viz zde výše 3.

2 - Viz zde výše 3, zvl. odst. 1 a 3-7.

3 - Ve školách - továrnách na "vzdělání“, ve školně továrním "vzdělávacím“ procesu - provozu, je výuka přizpůsobena a připodobněna továrnímu provozu veřejnému, jemuž vládne medializace; duch (antiduch) veřejného továrního provozu tedy vládne také ve školách - továrnách na „vzdělání“, ve školně továrním „vzdělávacím“ procesu - provozu, ve způsobech výuky: způsoby výuky jsou ovládnuty a proniknuty totální multimedialitou videoklipů, power-pointů etc.; 
nicotnosti se promítají na power-pointu a přednášející „přednášíi tak, že ty nicotnosti, na power-pointu promítané, prostě předčítá: předčítá prostě nadpisy, podnadpisy a hesla a promítá sloupcové diagramy, koláčové diagramy etc. - promítaje vizualizuje; takto tato totální multimedialita a vizualizace neumožňuje už skutečné myšlenky a znemožňuje skutečné myšlení s logickou argumentací, neb logická argumentace je ve sféře vizualizace (vizualizační povrchnosti a nicotnosti) též vyloučena a znemožněna. Znemožněním skutečného myšlení a skutečných myšlenek se znemožňuje i rozumění „věcem, o něž běži“" nejenže se „věci, o něž běži“, znicotňují - odbytostňují vyloučením lidsky bytostného -, ale též $\mathrm{v}$ tom zbytkovém - zbytkově znicotněném (vyloučením lidsky bytostného odbytostněném) je znemožněno rozumění bytnosti v nicotném, tzn. že je znemožněno hloubení vzdělanosti, pokud souvisí s rozuměním bytostně lidskému nebo alespoň s rozuměním bytnosti nicotného, a je možné (a nutné) jen šiření nevzdělanosti, pokud souvisí se znemožněním (popřením) rozumění bytostně lidskému i rozumění bytnosti nicotného.

4 - Viz zde výše 3, zvl. odst. 1 a 3-7.

5 - Viz zde výše pozn. 3 ad 4.

6 - Viz zde výše 3.

Ad 5. (Bytný základ zakládající a zacilující antiideje dnešního "vzdělávání", tj. i bytný základ zakládající a zacilující antiideje „vzdělávání" $\mathrm{v}$ dnešních „Vzdělávacích institucích“, tj. i ve školách jako „Vzdělávacích institucích“.)

1 - Srov. k tomu Kosíkovy „Předpotopní úvahy“.

Tento superkapitálový antiduch má neofeudální ráz:

projektem vlády neofeudálního superkapitálového antiducha je projekt antiosvícenství, tj. projekt zatemnění (znovuzatemnění) i víceméně (ba i sebeméně) osvíceného ducha (tj. ducha jedinečného i společenského).

Antiduch k tomu používá ekonomické vydírání

- viz a slyš dnes všude odkazy a poukazy na ekonomický tlak!:

vše je pod ním a vše je pro něj, tedy i vědění: pod „ekonomickým tlakem“ dnes všude (tedy i ve vědění) vláda (nadvláda) ekonomismu a ekonomistů;

ani nejvulgárnější marxismus natolik nezdůrazňoval roli „ekonomické základny“ v (,reálně socialistické“) společnosti,

nakolik zdůrazňuje roli „ekonomické základny“ ve vulgárně kapitalistické společnosti dnešní vulgární (antimarxistický) ekonomismus, tj. ekonomismus ve službách superkapitálového antiducha a industriálního provozu, resp. ve službách industriálního provozu superkapitálového antiducha. 
A týž antiduch k tomu využívá i mimoekonomické příkazy (namnoze přitom jde o kontrolu a ovládání skrze sebekontrolu ovládaných):

jimi i jím pokračuje - „pokrokuje“ - k svému cíli.

Tento „pokrok“, jímž pokračuje - „pokrokuje“ - k svému cíli, je největší krok zpět v novodobých společensko-lidských dějinách, to jest: největší krok zpět jsou (post)moderní společensko-lidské dějiny "pokroku“,

jež jsou absurdní

a jež ve své absurditě mají kafkovský ráz („nádech kafkovského světa“).

K nim patří taky dnešní liberalismus a ujištění a ujišt'ování dnešních liberálů, že „jiné cesty není“, resp. že „jiná možnost není“:

svoboda se vyhlašuje - proklamuje - jako nemožnost, jako vyloučenost svobody.

Dnešní liberálové jsou ideology vášnivé apologetiky (superkapitálového) antiducha industriálního provozu, tzn. i přisluhování (superkapitálovému) antiduchu industriálního provozu.

Dříve se takové přisluhování mělo za skutečný pád intelektuála (pokud tak či tak byl ještě duchovním člověkem a byl jako takový chápán).

Dnes se takové přisluhování má za právo skutečného intelektuála (pokud již nijak duchovním člověkem není a není jako takový chápán), ba i za jeho povinnost, tj. povinnost plynoucí z nutnosti, nikoli z jeho svobody.

Dnešní liberálové, jsouce ideology vášnivé apologetiky (superkapitálového) antiducha industriálního provozu, tzn. i přisluhování (superkapitálovému) antiduchu industriálního provozu,

jsou př́ikladem intelektuálů, již s duchovními lidmi již nemají nic společného.

Duchovní lidé nemají tedy dnes nic společného s intelektuály a jsou příkladem lidí,

již ještě chtějí a mohou být aktéry vzdělávání a vzdělanosti -

na rozdíl od oněch a $\mathrm{v}$ protikladu $\mathrm{k}$ oněm, již chtějí a mohou být už jen agenty pseudovzdělávání a nevzdělanosti:

pro ně (ujišstované a ujištěné dnešním liberalismem a dnešními liberály) ovšem „jiné cesty není", resp. „jiná možnost není",

nebot' též pro ně ovšem svoboda je pouze nemožnost, vyloučenost svobody.

2 - Srov. k tomu též Kosíkovy „Předpotopní úvahy“.

3 - Jen tam lze zůstat u věci, o niž běží (tj. u věci vzdělanosti a toho, co souvisí se vzdělaností a závisí na ní). 
Zmizela-li ze špinavého moře veřejného „vzdělávání“ (tj. veřejné nevzdělanosti),

je lépe ze špinavého moře veřejné nevzdělanosti (veřejného „vzdělávání“) zmizet za ní, připustí-li (neofeudální) superkapitálový antiduch, že lze před ním ještě někam zmizet

a neurčí-li týž (neofeudální) superkapitálový antiduch (v rámci definitivní normalizace a definitivní globalizace své vlády), že před ním již nikam zmizet nelze,

tj. že u věci vzdělanosti a toho, co souvisí se vzdělaností a závisí na ní, tj. u věci, o niž běží, nelze již nikde zůstat - ani na souostrovích, ani na ostrovech či ostrůvcích, tj. že všechna souostroví i všechny ostrovy i ostrůvky musejí být (dříve či později) odstraněny - zaplaveny.

\section{(K doslovu.)}

1 - Tj. (i) doby postmoderní, tak jak ji datují - a jak ji určují (?) - filosofové a historikové "postmoderny", resp. "postmoderní" filosofové a historikové, byt' sám Liessmann o ní vůbec nemluví a byt' sám Liessmann mluví pouze o době moderní.

2 - Pokud jde o fenomenální stránku věci, o niž zde běží, můžeme ji zcela svěřit Liessmannově "Teorii nevzdělanosti“: je V ní podána způsobem takřka vyčerpávajícím.

Pokud jde o esenciální stránku věci, o niž zde běží, můžeme v ní Liessmannovu „Teorii nevzdělanosti“ přeci jen zpřesnit; podat ji tady způsobem ne snad vyčerpávajícím, leč přeci jen přesnějším, tj. ucelenějším, prohloubenějším a přehlednějším,

o to jsem se zde výše pokusil. Pokusil jsem se o to zejména v souvislosti s tématem bytného základu zakládající a zacilující antiideje dnešního "vzdělávání", tj. i bytného základu zakládající a zacilující antiideje „vzdělávání“ v dnešních „vzdělávacích institucích“, tj. i ve školách jako „vzdělávacích institucích“, tj. s tématem vzhledem $\mathrm{k}$ této souvislosti základním. O tom základním, tj. o bytném základu zákládající a zacilující antiideje dnešního „vzdělávání“, tzn. i o bytném základu zakládající a zacilující antiideje „vzdělávání“ v dnešních „vzdělávacích institucích“, tj. i ve školách jako „vzdělávacích institucích“, toho Liessmann řekl nejméně a řekl to nejméně přesně, popř. se i dopustil dílčích omylů. Tak např. podle něho dnešní proměnění humanistické ideje univerzity (tj. dnešní znetvoření humanistické ideje univerzity) prý „Hegel nazývá“ - tzn.: Hegel by nazval - lstí rozumu. Avšak lest rozumu dle Hegela je jistý způsob nevědomého prosazení rozumných (duchovních) účelů ve vědomé činnosti lidí: lest rozumu je dle Hegela lstí světového ducha (vlády ducha ve světě); lest rozumu dle Hegela není žádným způsobem (ne)vědomého prosazení nerozumných (antiduchovních) účelů v (ne)vědomé činností lidí: lest rozumu není dle 
Hegela lstí světového antiducha (vlády antiducha nad světem), tzn. že Hegel ji nenazývá - resp. Hegel by ji nenazval - lstí rozumu. Zde např. se Liessmann dopustil dílčího omylu. Nicméně i přesto je Liessmann výrazným a významným pokračovatelem kritického (filosoficko-antropologického) myšlení myslitelů tzv. „frankfurtské školy“ i myslitelů - pokračovatelů v kritickém (filosofickoantropologickém) myšlení tzv. „frankfurtské školy“, např. a zvláště Kosíka, byt' i Liessmann nevládne pronikavostí a jasnozřivostí myšlení Kosíkova; avšak kdo touž pronikavostí a jasnozřivostí myšlení dnes vládne?

3 - Viz zde výše pozn. 1 k úvodu.

4 - Viz zde výše pozn. 2 k úvodu.

\section{K dodatku. (Škola - továrna a škola - stoka.)}

1 - Srov. K. Kosík: Pražské jaro, „konec dějin“ a „šaušpíler“; in: K. Kosík: Předpotopní úvahy.

2 - Jak už zde výše řečeno, K. P. Liessmann v „Teorii nevzdělanosti“ ovšem píše o šíření nevzdělanosti ve školách - továrnách na "vzdělání“; o šiřrení nevzdělanosti ve školách - stokách nevzdělavatelnosti K. P. Liessmann v „Teorii nevzdělanosti“ ovšem nepíše, jak už též výše řečeno, nebot' je nezná, nebot $v$ nich nepobýval. Ten, kdo je zná, nebot' $\mathrm{v}$ nich pobýval, může jeho pozorování šířící se nevzdělanosti mezi vzdělavatelnými na vyšší rovině dnešního školství rozšírit - a "prohloubit“ - o pozorování dnešního „školství“ na nejnižší rovině šiřící se nevzdělanosti mezi nevzdělavatelnými a doplnit tak jeho neúplný pohled o pohled do této bytné sféry antisféry simulace a imitace „vzdělávání“ nevzdělavatelných. Lepší nežli simulace a imitace „vzdělávání“ nevzdělavatelných by bylo zrušení „všeobecného vzděláváni“", jehož výsledkem je pouze všeobecná nevzdělanost - že pouze ta je jeho výsledkem, lze ukázat a dokázat kdykoli na komkoli z antiškolní stoky: zeptejte se kteréhokoli antistudenta této antiškoly na cokoli!, zeptejte se - a antistudent nebude vědět nic, nebude rozumět ničemu - nazítří i navždy; učitelství, které vede k takovým výsledkům, je absurdní učitelství; učitelství, které vede k takovým výsledkům a je s nimi spokojeno - srozuměno -, je (absurdní) podučitelstoí -, a podržení dílen a „výuky“ učňů v dílnách, při níž by se nepředstíralo žádné vzdělávání a př̀i níž by se nezastírala nevzdělavatelnost „učících se“ učňů.

3 - Právě v „Pražském jaru, „konci dějin“ a „šaušpíleru“ K. Kosíka i v jiných Kosíkových Předpotopních úvahách najde i dnešní antiředitel antiškoly svo̊j portrét; chce-li dnešní antiředitel antiškoly svůj portrét vidět, lze doporučit - vřele doporučit! - k přečtení. 


\section{E-LOGOS}

ELECTRONIC JOURNAL FOR PHILOSOPHY

Ročník/Year: 2013 (vychází průběžně/ published continuously)

Místo vydání/Place of edition: Praha

ISSN 1211-0442

Vydává/Publisher:

Vysoká škola ekonomická v Praze / University of Economics, Prague

nám. W. Churchilla 4

Czech Republic

13067 Praha 3

IČ: 61384399

Web: http://e-logos.vse.cz

Redakce a technické informace/Editorial staff and technical information:

Miroslav Vacura

vacuram@vse.cz

Redakční rada/Board of editors:

Ladislav Benyovszky (FHS UK Praha, Czech Republic)

Ivan Blecha (FF UP Olomouc, Czech Republic)

Martin Hemelík (VŠP Jihlava, Czech Republic)

Angelo Marocco (Pontifical Athenaeum Regina Apostolorum, Rome, Italy)

Jozef Kelemen (FPF SU Opava, Czech Republic)

Daniel Kroupa (ZU Plzeň, Czech Republic)

Vladimír Kvasnička (FIIT STU Bratislava, Slovak Republic)

Jaroslav Novotný (FHS UK Praha, Czech Republic)

Jakub Novotný (VŠP Jihlava, Czech Republic)

Ján Pavlík (editor-in-chief) (VŠE Praha, Czech Republic)

Karel Pstružina (VŠE Praha, Czech Republic)

Miroslav Vacura (executive editor) (VŠE Praha, Czech Republic) 